\title{
Tensile Properties of Duplex UNS S32205 and Lean Duplex UNS S32304 Steels and the Influence of Short Duration $475{ }^{\circ} \mathrm{C}$ Aging
}

\author{
Sérgio Souto Maior Tavares ${ }^{\mathrm{a} *}$, Juan Manuel Pardal ${ }^{\mathrm{a}}$, Hamilton Ferreira Gomes de Abreu \\ Cristiana dos Santos Nunes ${ }^{\mathrm{b}}$, Manoel Ribeiro da Silva ${ }^{\mathrm{c}}$ \\ ${ }^{a}$ Escola de Engenharia, Universidade Federal Fluminense - UFF, \\ Rua Passo da Pátria, 156, CEP 24210-240, Niterói, RJ, Brasil \\ ${ }^{\mathrm{b}}$ Departamento de Engenharia Metalúrgica e Materiais, Universidade Federal do Ceará - UFC, \\ Campus do Pici, Bloco 702, CEP 60455-760, Fortaleza, CE, Brasil \\ 'Instituto de Ciências Exatas, Universidade Federal de Itajubá - UNIFEI, Itajubá, MG, Brasil
}

Received: March 9, 2012; Revised: May 14, 2012

\begin{abstract}
Duplex stainless steels are high strength and corrosion resistant steels extensively used in the petrochemical and chemical industries. The aging at $475{ }^{\circ} \mathrm{C}$ for long periods of time provokes embrittlement and deterioration of corrosion resistance. However, short duration aging at $475^{\circ} \mathrm{C}$ may be used as heat treatment to improve mechanical resistance with small decrease in the other properties. In this work the flow stress curves of lean duplex UNS S32304 and duplex UNS S32205 steels were modeled with Hollomon's equation and work hardening exponents (n) were determined. The analyses were conducted in specimens annealed and heat treated at $475^{\circ} \mathrm{C}$ for short periods of time. The aging at $475{ }^{\circ} \mathrm{C}$ for 4 hours, 8 hours and 12 hours promoted significant hardening with small decrease of ductility. The work hardening exponents of both steels were compared, being higher in the duplex steel than in the lean duplex grade.
\end{abstract}

Keywords: duplex stainless steel, heat treatment, tensile properties, work hardening exponent

\section{Introduction}

The use of austenitic-ferritic stainless steels has been increasing inside industry environment, replacing traditional austenitic grades for a number of components. The success of this subclass of stainless steels is due to its excellent combination of corrosion resistance, mechanical resistance and toughness.

For many applications of austenitic-ferritic steels, where high corrosion resistance and low temperature toughness are necessary, the maximum service temperature allowed is $350{ }^{\circ} \mathrm{C}$. The reason is because the long term aging in the $350-550{ }^{\circ} \mathrm{C}$ may provoke the precipitation of very fine Cr-rich particles formed by spinodal decomposition mechanism from the ferrite phase $(\delta)$. This reaction is commonly written as $\delta \rightarrow \alpha^{\prime}+\alpha^{\prime \prime}$, where $\alpha^{\prime}$ is the chromium rich precipitates and $\alpha$ " is the Cr-depleted ferrite matrix ${ }^{1-5}$. It is worth noting that in the literature $\alpha^{\prime}$ is also used to designate the bcc magnetic martensite which appears in many austenitic and duplex stainless steels subjected to cold deformation ${ }^{6-9}$. These two different phases may occur in duplex and lean duplex stainless steels. In this work, $\alpha$ ' refers to the small Cr-rich precipitates formed through the spinodal decomposition of ferrite.

Several previous works have shown that the kinetics of $\alpha$ ' precipitation is higher at $475^{\circ} \mathrm{C}$. The deterioration of mechanical and corrosion resistance properties of duplex and superduplex aged at this temperature were also extensively

*e-mail: ssmtavares@terra.com.br reported ${ }^{1-5}$. However, short duration treatments may be used to improve mechanical resistance with minimum decrease of other properties. For instance, in the work of Marques et al. ${ }^{10}$ the abrasion wear resistance of a superduplex steels was increased by aging at $475{ }^{\circ} \mathrm{C}$ for periods of time up to 12 hours without embrittlement and corrosion resistance decay.

The UNS S32205 steel is a wrought duplex stainless steel grade very similar to the more traditional grade UNS S31803. Both contain low carbon $(<0.03$ wt. $(\%))$ and average contents $22 \% \mathrm{Cr}, 5 \% \mathrm{Ni}$ and $3 \% \mathrm{Mo}$, but the UNS S32205 has a more controlled and higher nitrogen content (0.14-0.20 wt. (\%) N) than the UNS S31803 (0.08-0.20\%).

The UNS S32304 is a lean duplex grade with average composition $23 \% \mathrm{Cr}, 4 \% \mathrm{Ni}, 0.10 \% \mathrm{~N}$ and low carbon $(<0.03 \%)$. Its corrosion resistance is lower than duplex grades due to the lower Mo addition (0.05-0.60\%) (wt. (\%)).

In this work the effects of short duration heat treatments on the tensile mechanical properties of UNS S32304 and UNS S32205 steels were investigated.

\section{Experimental}

Two sheets of $1.8 \mathrm{~mm}$ of thickness of duplex UNS S32205 and UNS S32304 with chemical compositions shown in Table 1 were studied. In this work the nomenclatures duplex (or DP) and lean duplex (or LD) will be used to the two steels investigated. 
Table 1. Chemical composition of duplex (UNS S32205) and lean duplex (UNS S32304) steels.

\begin{tabular}{ccccccccccc}
\hline Steel & Cr & Ni & Mo & Mn & Si & N & C & P & S \\
\hline UNS S32205 & 22.5 & 5.30 & 2.90 & 1.85 & 0.32 & 0.17 & 0.02 & 0.03 & $<0.001$ \\
UNS S32304 & 22.4 & 3.59 & 0.22 & 0.93 & 0.41 & 0.13 & 0.02 & 0.02 & $<0.001$ \\
\hline
\end{tabular}

The materials were received in the as solution treated (annealed) with austenitic ferritic microstructure. The ferrite and austenite contents of the materials were determined by quantitative metallography with specimens prepared with Behara's etching $(80 \mathrm{~mL}$ distilled water, $20 \mathrm{~mL} \mathrm{HCl}, 0.3 \mathrm{~g}$ of potassium metabissulfite).

Specimens for tensile tests were machined according to ASTM A-370-09 standard $^{11}$. Specimens for hardness tests were cut with $10 \times 10 \times 1.8 \mathrm{~mm}^{3}$ dimensions.

After cutting, the hardness specimens were aged at $475^{\circ} \mathrm{C}$ for different periods of time up to 14 hours. Vickers Hardness tests were performed with load of $30 \mathrm{kgf}$. The hardness curves were used to select the conditions for tensile tests.

After machining the tensile specimens were heat treated at $475{ }^{\circ} \mathrm{C}$ for 4 hours, 8 hours and 12 hours. The tensile tests were performed with constant velocity of $12 \mathrm{~mm} / \mathrm{min}$ at $22 \pm 2{ }^{\circ} \mathrm{C}$. Nominal and true stress-strain curves were obtained. Yield and ultimate strengths, elongation, absorbed energy and work hardening exponent were the parameters obtained from the tensile tests analysis.

Magnetization curves of unaged specimens of duplex and lean duplex steels were obtained in a Vibrating Sample Magnetometer (VSM). The maximum applied field was 1.4 T. The specimens for VSM were carefully cut from three regions of the fractured tensile test specimens: i) undeformed part (head); ii) uniform deformation region; and iii) localized deformation region (neck and fracture). The magnetic tests were conducted to evaluate the formation of bcc martensite induced by plastic deformation in both steels.

\section{Results}

Figures 1a, b show the microstructures of the materials in the as received condition. The ferrite contents measured by quantitative metallography in 10 fields were $(59.3 \pm 4.0) \%$ in the lean duplex, and $(58.5 \pm 3.0) \%$ in the duplex steel.

Figure 2 shows the hardness curves for both steels aged at $475^{\circ} \mathrm{C}$ up to 14 hours. The hardening due to $\alpha$ ' formation is faster and more intense in duplex steel than in lean duplex. The age hardening at $475^{\circ} \mathrm{C}$ is restricted to the ferrite phase, where $\mathrm{Mo}$ and $\mathrm{Cr}$ are concentrated. Observing that the $\mathrm{Cr}$ contents are similar in both steels, the more pronounced hardening of duplex steel may be attributed to the influence of Mo on the intensity and kinetics of $\alpha$ ' precipitation.

The hardness increase of duplex steel with aging for 4 hours, 8 hours and 12 hours were $48( \pm 7)$ HV, $58( \pm 8)$ $\mathrm{HV}$ and $60( \pm 8) \mathrm{HV}$, respectively. The hardness variation in lean duplex for the same periods of aging time were $43( \pm 7)$ $\mathrm{HV}, 50( \pm 8) \mathrm{HV}$ and $51( \pm 9) \mathrm{HV}$. The heat treatments for 4 hours, 8 hours and 12 hours were selected for a more detailed analysis with tensile tests.

Figures $3 \mathrm{a}$, b show the nominal stress-strain curves of duplex and lean duplex, respectively. The yield limit $\left(\sigma_{\mathrm{Y}}\right)$

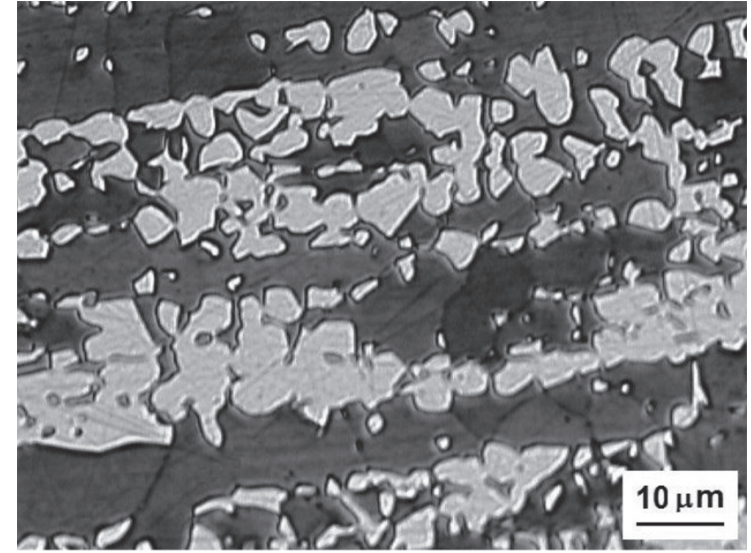

(a)

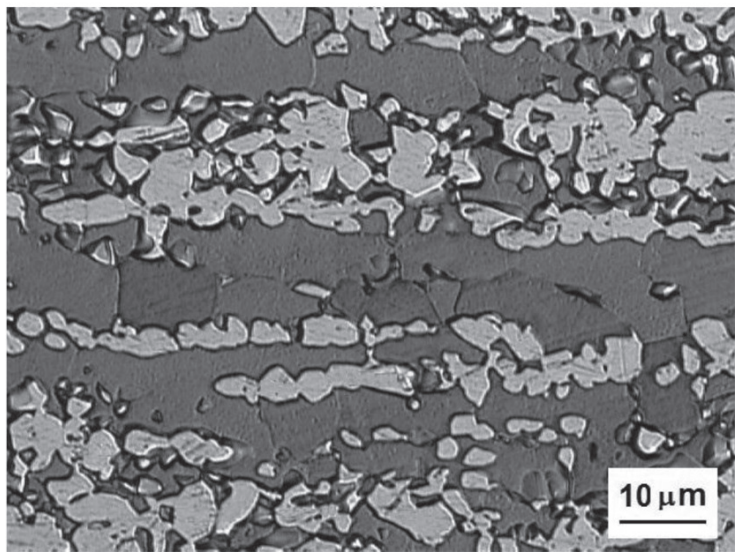

(b)

Figure 1. Microstructures of a) duplex and b) lean duplex steels investigated.

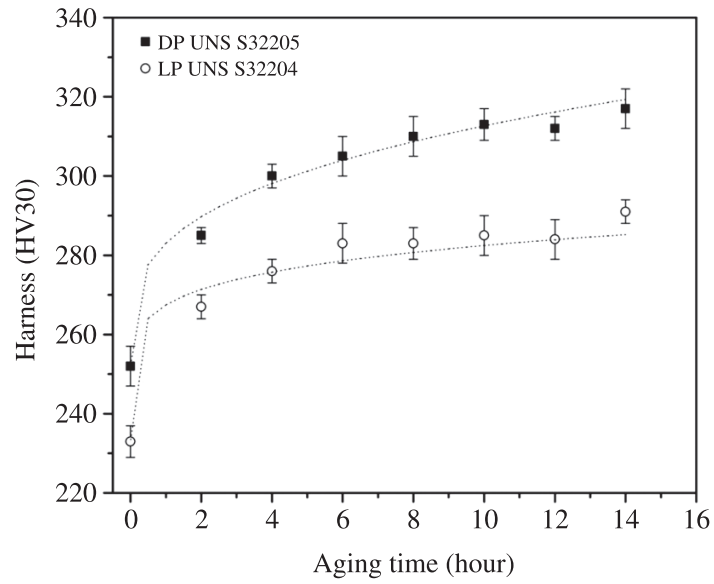

Figure 2. Age hardening curves of DP UNS S32205 and LD UNS S32304 for aging at $475^{\circ} \mathrm{C}$. 
and ultimate strength $\left(\sigma_{\mathrm{UTS}}\right)$, total elongation (Elong.) and uniform ductility (El-U) obtained from the curves and from the final dimensions of the fractured specimens are shown in Table 2. From these data, the short duration aging produces significant increase of $\sigma_{\mathrm{Y}}$ and $\sigma_{\mathrm{UTS}}$ with some decrease of ductility parameters (Elong. and El-U). In duplex steel, the increase of aging time from 8 hours to 12 hours did increase significantly $\sigma_{\mathrm{Y}}$ and $\sigma_{\mathrm{UTS}}$.

True stress-strain curves, also known as flow stress curves, were obtained from the nominal stress and strain points. Figures $4 \mathrm{a}$, b show the curves of unaged duplex

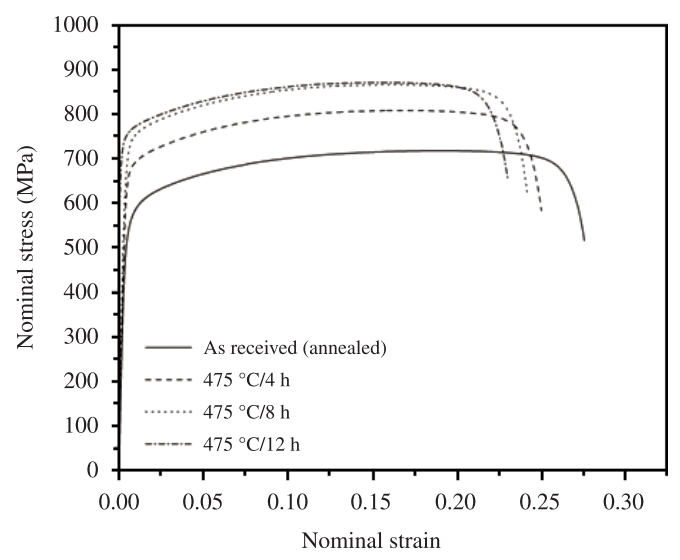

(a)

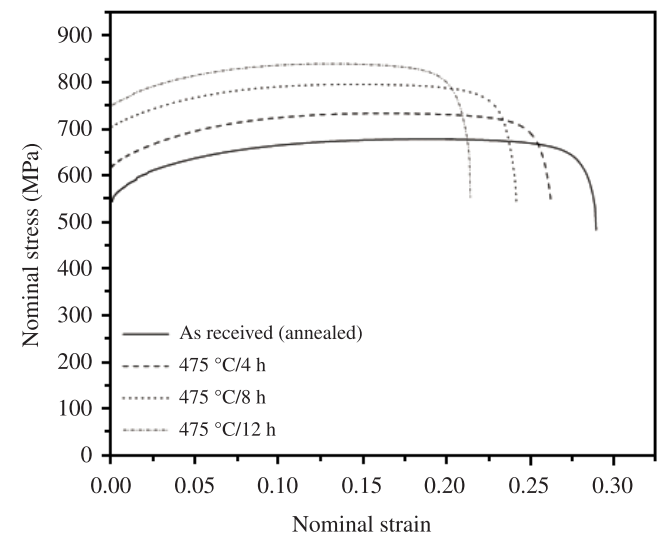

(b)

Figure 3. Nominal stress versus nominal strain curves of a) DP UNS S32205 and b) LD UNS S32304. and lean duplex specimens, respectively. The curves were modeled using the Hollomon's equation (Equations 1, 2) ${ }^{12}$ :

$\sigma=K \varepsilon^{n}$

$\ln \sigma=\ln K+n \ln \varepsilon$

where $\sigma$ is the true stress, $\varepsilon$ is the true strain, $K$ is a constant and $\mathrm{n}$ is the work hardening exponent.

Figure 5 shows the plot of $\ln \sigma$ versus $\ln \varepsilon$ for duplex steel as received (annealed). First, the whole curve was modeled by one Hollomon equation, finding $\ln \mathrm{K}=6.874$ and

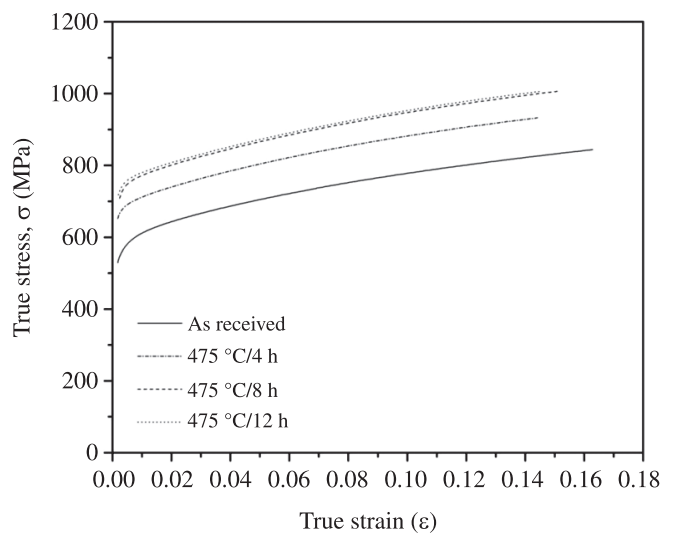

(a)

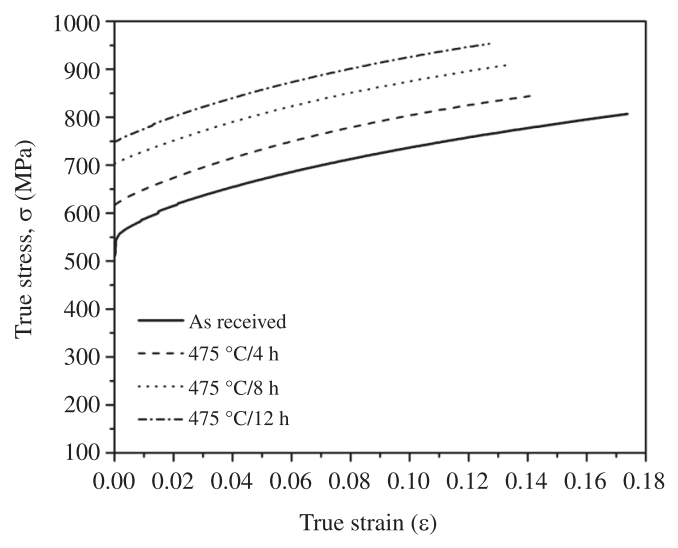

(b)

Figure 4. True stress versus true strain curves of a) DP UNS S32205 and b) LD UNS S32304.

Table 2. Tensile mechanical properties of duplex and lean duplex studied as function of the aging treatment at $475^{\circ} \mathrm{C}$.

\begin{tabular}{cccccc}
\hline Steel & Aging & $\sigma_{\mathbf{Y}}(\mathbf{M P a})$ & $\sigma_{\text {UTS }}(\mathbf{M P a})$ & Elong. $(\%)$ & El-U $(\%)$ \\
\hline \multirow{4}{*}{ duplex } & unaged & 535 & 717 & 27.7 & 19.9 \\
& $475^{\circ} \mathrm{C} / 4$ hours & 651 & 807 & 25.0 & 17.0 \\
& $475^{\circ} \mathrm{C} / 8$ hours & 695 & 865 & 24.1 & 16.7 \\
& $475^{\circ} \mathrm{C} / 12$ hours & 708 & 670 & 23.2 & 16.2 \\
Lean duplex & unaged & 510 & 678 & 29.0 & 19.3 \\
& $475^{\circ} \mathrm{C} / 4$ hours & 617 & 796 & 24.1 & 16.3 \\
& $475^{\circ} \mathrm{C} / 8$ hours & 707 & 840 & 21.4 & 14.4 \\
\hline
\end{tabular}


$\mathrm{n}=0.099$, with correlation coefficient $\mathrm{R}^{2}$ equal 0.975 (Figure 5a). A better correlation was obtained by dividing the curve in two parts and fitting the with two Hollomon's equations, as shown in Figure 5b. Two work hardening exponents were measured by this way: $n_{1}=0.079$ for the first part of the curve, and $n_{2}=0.134$ for the second part. Figures $6 \mathrm{a}, \mathrm{b}$ show the comparison of the models and the experimental points in the flow stress curve.

The same behavior was observed in specimens of duplex steel aged at $475{ }^{\circ} \mathrm{C}$, i.e., the fitting with one equation could be performed, but a better correlation was obtained by dividing the curve and fitting with two Hollomon's equations. Table 3 shows the values of constant $\mathrm{K}$ and work hardening exponents found with one and two

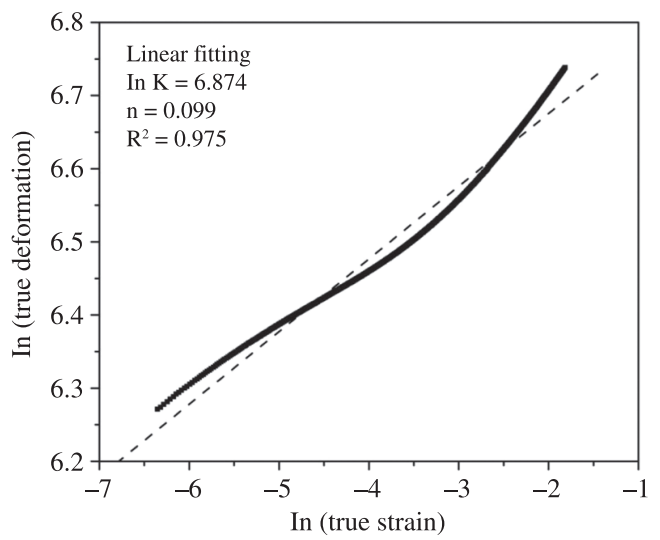

(a)

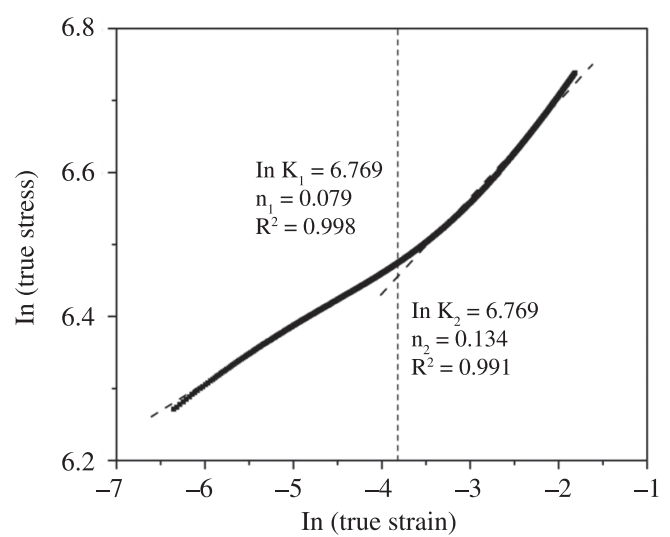

(b)

Figure 5. Plots of $\ln$ (true stress) versus $\ln$ (true strain) for unaged duplex steel: a) fitting with one Hollomon's equation; b) fitting with two Hollomon's equations. equations models for the duplex steel. In all cases, the $\mathrm{K}$ value obtained with one equation model was placed between $\mathrm{K} 1$ and $\mathrm{K} 2$ from two equations model. The same was observed in the comparison of $n$ with $n 1$ and $n 2$. It can be observed that $\mathrm{n}$ was between $\mathrm{n} 1$ and $\mathrm{n} 2$ because the curve that was firstly fitted with one line with slope n, was then divided in two lines, one with a lower slope (n1) and other with a higher slope (n2).

Figures $7 \mathrm{a}, \mathrm{b}$ show the curves of $\ln \sigma$ versus lne of lean duplex specimens unaged and treated at $475^{\circ} \mathrm{C}$ for 4 hours. In these cases, the modeling with one equation resulted in bad correlation coefficients $\left(\mathrm{R}^{2}<0.90\right)$. Modeling with two equations was so performed in all lean duplex specimens, with results shown in Table 4.

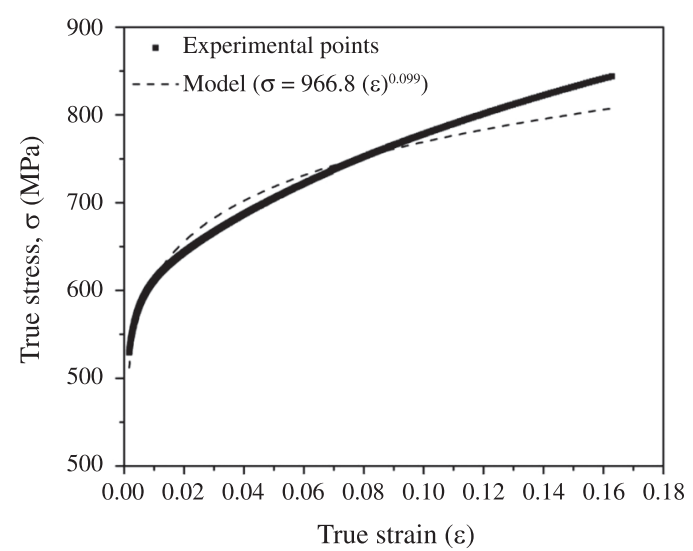

(a)

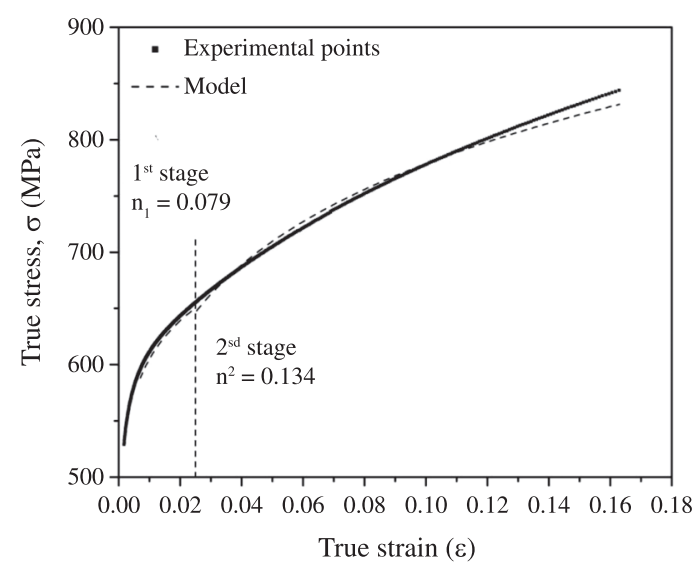

(b)

Figure 6. Comparison of the two models with experimental points for unaged duplex steel: a) one Hollomon's equation; b) two Hollomon's equations.

Table 3. Values of $\mathrm{K}, \mathrm{K}_{1}, \mathrm{~K}_{2}, \mathrm{n}, \mathrm{n}_{1}$ and $\mathrm{n}_{2}$ obtained with one equation and two equations models for flow stress curves of duplex steel.

\begin{tabular}{ccccccc}
\hline \multirow{2}{*}{$\begin{array}{c}\text { Heat } \\
\text { treatment }\end{array}$} & \multicolumn{2}{c}{ One equation model } & \multicolumn{4}{c}{ Two equations model } \\
\cline { 2 - 7 } & $\mathbf{K}$ & $\mathbf{n}$ & $\mathbf{K}_{1}$ & $\mathbf{n}_{\mathbf{1}}$ & $\mathbf{K}_{\mathbf{2}}$ & $\mathbf{n}_{\mathbf{2}}$ \\
\hline unaged & 966.8 & 0.099 & 870.5 & 0.079 & 1060.2 & 0.134 \\
$475^{\circ} \mathrm{C} / 4$ hours & 1035.9 & 0.080 & 893.3 & 0.049 & 1164.5 & 0.122 \\
$475^{\circ} \mathrm{C} / 8$ hours & 1121.9 & 0.081 & 987.6 & 0.053 & 1260.3 & 0.124 \\
$475^{\circ} \mathrm{C} / 12$ hours & 1112.0 & 0.076 & 976.8 & 0.048 & 1264.0 & 0.123 \\
\hline
\end{tabular}


Magnetization curves of samples cut from different parts of the tensile specimens of unaged lean duplex are shown in Figure 8. Magnetization saturation $\left(\mathrm{m}_{\mathrm{s}}\right)$ values extracted from the magnetization curves of undeformed duplex and lean duplex are shown in Table 5. Analyzing the results of lean duplex, the sample taken from the undeformed region presented $\mathrm{m}_{\mathrm{s}}$ equal $70.1 \mathrm{Am} 2 . \mathrm{kg}^{-1}$. The $\mathrm{m}_{\mathrm{s}}$ of the sample from the uniform deformation region was $80.6 \mathrm{Am} 2 . \mathrm{kg}^{-1}$, and in the localized deformation region the $\mathrm{m}_{\mathrm{s}}$ has increased to $95.6 \mathrm{Am} 2 . \mathrm{kg}^{-1}$. This increase of magnetization saturation with plastic deformation indicates that part of the austenite phase was transformed into magnetic bcc martensite during the tensile test of lean duplex. On the other hand, the duplex steel did not show increase of $m_{s}$ with deformation, which indicates that martensitic transformation did not occur during the tensile test. A previous work on duplex steel has shown that significant martensitic transformation in UNS S31803 (similar to duplex UNS S32205) was only detected after true deformations higher than 1.0 by cold rolling ${ }^{13}$.

The division of the flow stress into two parts, each of them with one work hardening exponent indicates that the material has two work hardening stages. The two work hardening stages are much clearer and well defined in the lean duplex steel than in duplex steel. This difference may be related to the higher susceptibility of lean duplex to martensitic transformation, as observed by magnetic measurements.

Figure 9 shows the work hardening exponents of duplex and lean duplex steels as function of aging treatments. In lean duplex steel there is a clear trend of decrease of work hardening exponents with the increase of aging time. Duplex steel also shows this trend in the first 4 hours of aging. After this period of time the work hardening exponents remain unaltered by the increase of aging time.

In austenitic stainless steels the high work hardening exponent is somewhat related to deformation induced martensitic transformation during plastic deformation. However, a comparison between lean duplex and duplex

Table 4. Values of $\mathrm{K}_{1}, \mathrm{~K}_{2}, \mathrm{n}, \mathrm{n}_{1}$ and $\mathrm{n}_{2}$ obtained with two equations models for flow stress curves of lean duplex steel.

\begin{tabular}{ccccc}
\hline $\begin{array}{c}\text { Heat } \\
\text { treatment }\end{array}$ & $\mathbf{K}_{\mathbf{1}}$ & $\mathbf{n}_{\mathbf{1}}$ & $\mathbf{K}_{\mathbf{2}}$ & $\mathbf{n}_{\mathbf{2}}$ \\
\hline $\begin{array}{c}\text { Unaged } \\
475^{\circ} \mathrm{C} / 4 \text { hours }\end{array}$ & 681.7 & 0.032 & 969.2 & 0.119 \\
$475^{\circ} \mathrm{C} / 8$ hours & 800.0 & 0.025 & 1022.5 & 0.109 \\
$475^{\circ} \mathrm{C} / 12$ & 832.8 & 0.020 & 1084.3 & 0.096 \\
hours & & & 1108.9 & 0.083 \\
\hline
\end{tabular}

Table 5. Magnetizations saturation $\left(\mathrm{m}_{\mathrm{s}}\right)$ of samples collected from tensile tests specimens (after test).

\begin{tabular}{lcc}
\hline \multirow{2}{*}{ Region of tensile test specimen } & \multicolumn{2}{c}{$\mathbf{m}_{\mathbf{s}}\left(\mathbf{A m}^{2} \mathbf{. k g}^{-1}\right)$} \\
\cline { 2 - 3 } & $\begin{array}{c}\text { Lean } \\
\text { duplex }\end{array}$ & Duplex \\
\hline Undeformed (head) & $78.1 \pm 1.3$ & $70.2 \pm 1.5$ \\
Uniform deformation & $80.6 \pm 1.0$ & $69.0 \pm 2.0$ \\
$\begin{array}{l}\text { Localized deformation (neck and } \\
\text { fracture) }\end{array}$ & $95.6 \pm 1.8$ & $70.2 \pm 1.3$ \\
\hline
\end{tabular}

steels shows that the higher work hardening exponents were found in the material less susceptible to martensitic transformation, i.e., duplex steel.

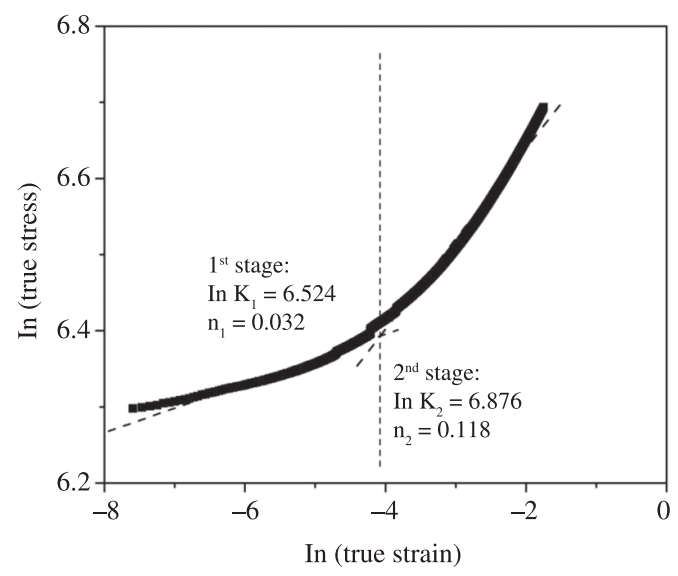

(a)

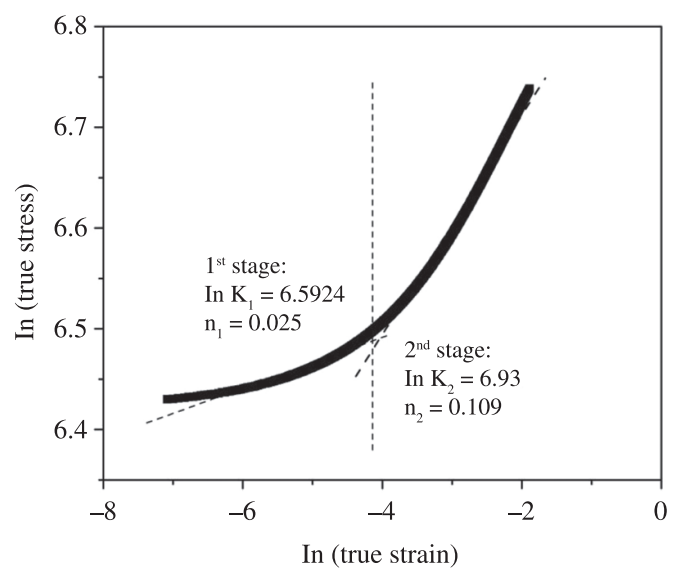

(b)

Figure 7. Plots of $\ln$ (true stress) versus $\ln$ (true strain) for lean duplex steel: a) unaged; b) aged at $475^{\circ} \mathrm{C}$ for 4 hours.

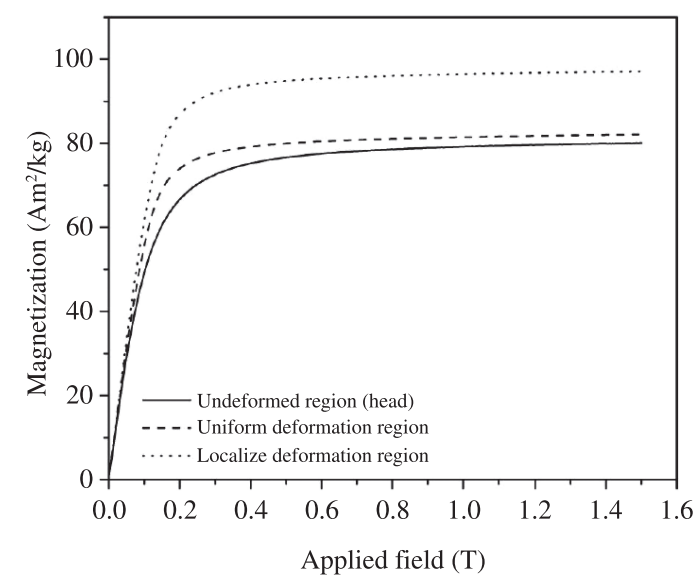

Figure 8. Magnetization curves from samples taken from three regions of the tensile tested specimen: undeformed region (head), uniform deformation region, and localized deformation region (neck and fracture). 


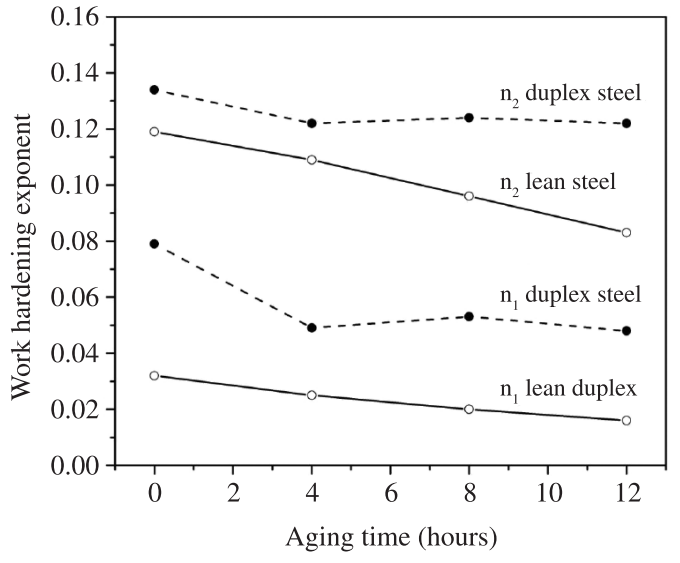

Figure 9. Variation of work hardening exponents of lean duplex and duplex steels with aging time at $475^{\circ} \mathrm{C}$.

\section{Conclusions}

The flow stress curves of duplex UNS S32205 steel could be reasonably modeled by simple Hollomon's equations. However, better fittings were obtained by

\section{References}

1. Chandra K, Singhal R, Kain V and Raja VS. Low temperature embrittlement of duplex stainless steel: Correlation between mechanical and electrochemical behavior. Materials Science and Engineering. 2010; 527:3904-3912. http://dx.doi. org/10.1016/j.msea.2010.02.069

2. Sahu JK, Krupp U, Ghosh RN and Christ H-J. Effect of $475^{\circ} \mathrm{C}$ embrittlement on the mechanical properties of duplex stainless steel. Materials Science and Engineering: A. 2009; 508:1-14. http://dx.doi.org/10.1016/j.msea.2009.01.039

3. Weng KL, Chen HR and Yang JR. The low-temperature aging embrittlement in a 2205 duplex stainless steel. Materials Science and Engineering: A. 2004; 379:119-132. http://dx.doi. org/10.1016/j.msea.2003.12.051

4. Tavares SSM, Terra VF, Lima Neto P and Matos D. Corrosion resistance evaluation of the UNS S31803 duplex stainless steels aged at low temperatures $\left(350\right.$ to $550{ }^{\circ} \mathrm{C}$ ) using DLEPR tests. Journal of Materials Science. 2005; 40:4025-4028. http:// dx.doi.org/10.1007/s10853-005-1993-9

5. Maeda N, Goto T, Kamimura T, Naito T, Kumano S and Nakao Y. Changes in electromagnetic properties during thermal aging of duplex stainless steel. International Journal of Pressure Vessels and Piping. 1997; 71:7-12. http://dx.doi.org/10.1016/ S0308-0161(96)00015-4

6. Seetharaman V and Krishnan R. Influence of the martensitic transformation on the deformation behaviour of an AISI 316 stainless steel at low temperatures. Journal of Materials Science. 1981; 16:523-530. http://dx.doi.org/10.1007/ BF00738646 dividing the flow curve in two parts and modeling with two Hollomon's equations, which resulted in two work hardening exponents.

Lean duplex UNS S32304 could only be modeled by two Hollomon's equation, each one corresponding to a work hardening stage.

Differently from duplex steel, lean duplex showed the transformation $\gamma \rightarrow$ bcc martensite during plastic deformation in tensile test, as concluded by magnetization saturation tests.

Lean duplex UNS S32304 and duplex UNS S32205 steels may be hardened by short duration heat treatments at $475{ }^{\circ} \mathrm{C}$. Although a small decrease of ductility is also observed, heat treatments for 4 hours and 8 hours and 12 hours may be good options to increase the yield and strength limits.

The aging at $475{ }^{\circ} \mathrm{C}$ also promoted the decrease of work hardening exponents of Hollomon's equations of lean duplex steel.

\section{Acknowledgements}

The authors aknowledge the Brazilian Research Agency CNPq for financial support.
7. Abreu HFG, Gomes da Silva MJ, Maia do Nascimento A and Freitas FNC. Stress induced martensite transformation texture in AISI 304 austenitic stainless steel. Materials Science and Technology. 2011; 27(11):1627-1631. http://dx.doi.org/10.11 79/026708310X12852304599906

8. Tavares SSM, Maria Neto J, Silva MR, Vasconcelos IF and Abreu HFG. Magnetic properties and $\alpha^{\prime}$ martensite quantification in an AISI 301LN stainless steel deformed by cold rolling. Materials Characterization. 2008; 59:901-904. http://dx.doi.org/10.1016/j.matchar.2007.07.007

9. Reick W, Pohl M and Padilha AF. Determination of stacking fault energy of austenite in a duplex stainless steel. Steel Research. 1996; 67(6):253-256.

10. Marques F, Silva WM, Pardal JM, Tavares SSM and Scandian C. Influence of heat treatments on the micro-abrasion wear resistance of a superduplex stainless steel. Wear. 2011; 271:1288-1294. http://dx.doi.org/10.1016/j. wear.2010.12.087

11. American Society for Testing and Materials-ASTM. E-370-09: Standard Test Methods and Definitions for Mechanical Testing of Steel Products. ASTM; 2009.

12. Dieter GE. Mechanical Metallurgy. Singapore: McGraw Hill; 1988. p. 287-288.

13. Tavares SSM, Silva MR, Pardal JM, Abreu HFG and Gomes AM. Microstructural changes produced by plastic deformation in the UNS S31803 duplex stainless steel. Journal of Materials Processing Technology. 2006; 180:318-322. http://dx.doi. org/10.1016/j.jmatprotec.2006.07.008 